\title{
Climate Change and Mercury Accumulation in Canadian High and Subarctic Lakes
}

\author{
JANE L. KIRK** ${ }^{\dagger}$, DEREK C.M. MUIR ${ }^{\dagger}$, DERMOT ANTONIADES ${ }^{\perp}$, MARIANNE S.V. \\ DOUGLAS ${ }^{\mathbb{I l}}$, MARLENE S. EVANS ${ }^{\ddagger}$, TOGWELL A. JACKSON ${ }^{\dagger}$, HEDY KLING ${ }^{\S}$, SCOTT \\ LAMOUREUX ${ }^{\ddagger}$, DARLENE S. S. LIM ${ }^{\circ}$, REINHARD PIENITZ ${ }^{\perp}$, JOHN P. SMOL ${ }^{\infty}$, KAILEY \\ STEWART $^{\ddagger}$, XIAOWA WANG ${ }^{\dagger}$, FAN YANG $^{\dagger}$
}

Aquatic Ecosystem Protection Research Division, Environment Canada, Burlington, ON, Canada $L 7 R 4 A 6$

Centre d'études nordiques, Université Laval, Quebec, QC, Canada GIV OA6

Canadian Circumpolar Institute, University of Alberta, Edmonton, AB, Canada T6G 1K8

Aquatic Ecosystem Protection Research Division, Environment Canada, Saskatoon, SK, Canada S7N $3 H 5$

Algal Taxonomy and Ecology, Winnipeg, MB, Canada R3T 2X8

Department of Geography, Queen's University, Kingston, ON, Canada K7L 3N6

SETI Institute, Mountain View, CA, United States 94043-2172

Department of Biology, Queen's University, Kingston, ON, Canada K7L 3N6

*Corresponding author phone: (905) 336-4712; fax: (905) 336-6430 e-mail: Jane.Kirk@ec.gc.ca.

${ }^{\dagger}$ Canadian Centre for Inland Waters, Environment Canada.

${ }^{\perp}$ Centre d'études nordiques, Université Laval.

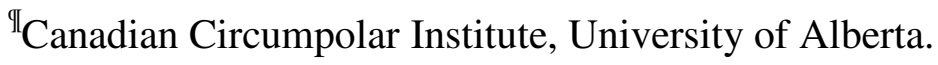

${ }^{\ddagger}$ National Water Research Institute, Environment Canada.

${ }^{\S}$ Algal Taxonomy and Ecology.

¥ Department of Geography, Queen’s University.

${ }^{\circ}$ SETI Institute.

${ }^{\infty}$ Department of Biology, Queen's University. 
There are 15 pages of supporting information including details on sample collection and analysis, additional results and discussion, 1 table, and 8 figures. Table $\mathrm{S} 1$ provides details on lake and sediment characteristics of 14 Canadian high and subarctic lakes cored between 2000-2005. Figure $\mathrm{S} 1 \mathrm{~A}-\mathrm{N}$ shows excess ${ }^{210} \mathrm{~Pb}$ versus accumulated dry weight measured in sediment cores from 13 Canadian high and subarctic lakes and ${ }^{137} \mathrm{Cs}$ versus depth for one high Arctic lake. Figure S2 illustrates the relationship between average sedimentation rate and latitude in 14 Canadian high and subarctic lakes. Figure S3A-N shows sedimentation rate and mercury $(\mathrm{Hg})$ concentration through time while Figure S4A-N shows Hg fluxes adjusted for sediment particle focusing $\left(\mathrm{HgF}_{\mathrm{F}}\right)$ compared to $\mathrm{HgF}_{\mathrm{F}}$ adjusted for post-industrialization increases in sedimentation rate $\left(\mathrm{HgF}_{\mathrm{F}, \text { adj }}\right)$ in the 14 study lakes. Figure $\mathrm{S} 5 \mathrm{~A}-\mathrm{N}$ shows sedimentation rate and algal derived carbon (C) or S2 concentration through time while Figure S6 demonstrates the ratio of S2 to residual $\mathrm{C}(\mathrm{RC})$ through time in the study lakes. Figure S7 is a Van Krevelen diagram, or a plot of average sediment hydrogen index (HI) and oxygen index (OI) while Figure S8A-N shows S2 flux through time in the study lakes.

\section{Additional methods}

Site selection and sample collection: Sediment cores were obtained from the deepest point in each lake using gravity corers designed to retrieve undisturbed, high-resolution profiles (1) using 6-10 cm diameter acrylic plastic tubes. Cores from most lakes were obtained from a small boat or a float-equipped aircraft during the open water season whereas cores from Cli, West, and Hazen lakes were obtained through holes drilled through the ice. The deepest point in each lake was located by sonar, or by using bathymetric maps, avoiding sloped areas that may be subject to slumping. All cores were composed of fine-grained sediment and were sliced into 0.5 or $1 \mathrm{~cm}$ sections (Table S1). Sediments were stored in WhirlPak $^{\mathrm{R}}$ polyethylene bags or in wide-mouth polypropylene jars and were kept in cool dark storage during the field work and then shipped by air to the laboratory where they were stored in the dark at $4^{\circ} \mathrm{C}$.

Mercury (Hg) and aluminum (Al) concentrations: Sediment $\mathrm{Hg}$ concentrations were determined at the National Laboratory for Environmental Testing (NLET, Burlington, ON) by digestion with hot nitric and hydrochloric acids $(\mathrm{HCl})$ and hydrogen peroxide $\left(\mathrm{H}_{2} \mathrm{O}_{2}\right)$ (ratio 9:2:1) in Teflon ${ }^{\circledR}$ vessels followed by detection by cold vapor atomic absorption spectrometry (CVFAS). Certified reference materials (Natural Resource Council, Canada MESS-3 and NIST RM 8704) were consistently within $\pm 7 \%$ of the certified values. Total aluminum (Al) was also determined by NLET by inductively coupled plasma-mass spectrometry (PQ-2, VG Elemental). 
Core dating and flux calculations: ${ }^{210} \mathrm{~Pb}$ activities were measured in each core and sedimentation rates and dates were calculated using the Constant Rate of Supply (CRS) model (2) with the exception of Lake Hazen where ${ }^{137} \mathrm{Cs}$ was used (3). Hg and S2 fluxes (HgF and S2F), post-industrialization fluxes $(\Delta \mathrm{HgF}$ and $\Delta \mathrm{HgS} 2)$, flux ratios (FR) and enrichment factors (EFs) were calculated as follows:

$\mathrm{F}\left(\mu \mathrm{g} \mathrm{m}^{-2} \mathrm{y}^{-1}\right)=$ Concentration $\left(\mu \mathrm{g} \mathrm{g}^{-1}\right) \mathrm{x}^{210} \mathrm{~Pb}$-derived sedimentation rates for each core horizon $\left(\mathrm{g} \mathrm{m}^{-2} \mathrm{y}^{-1}\right)$

$\Delta \mathrm{F}\left(\mu \mathrm{g} \mathrm{m}^{-2} \mathrm{y}^{-1}\right)=\mathrm{F}_{\text {recent }}$ (post-1990) - $\mathrm{F}_{\text {pre-ind }}$ (pre-industrial; pre-1850)

$\mathrm{FR}=\mathrm{F}_{\text {recent }} / \mathrm{F}_{\text {pre-ind }}$

$\mathrm{EF}=$ recent $/$ pre-industrial concentrations

Excess ${ }^{210} \mathrm{~Pb}$ activity was low in our cores, particularly in those from the high Arctic. ${ }^{210} \mathrm{~Pb}$ deposition is known to decline exponentially with latitude and, in North America, is approximately 5-fold lower at $60^{\circ} \mathrm{N}$ than at $30^{\circ} \mathrm{N}$ because of lower precipitation at higher latitudes $(4,5)$. In the high Arctic, permafrost may also reduce radon gas (the parent of ${ }^{210} \mathrm{~Pb}$ ) emissions from soil and extended periods of ice cover may prevent atmospheric ${ }^{210} \mathrm{~Pb}$ from reaching lake sediments $(5,6)$. Sediment particle focusing factors $(\mathrm{FF})$ were therefore estimated for all cores dated by dividing the observed ${ }^{210} \mathrm{~Pb}$ flux $\left(\mathrm{Bq} \mathrm{m}^{-2} \mathrm{y}^{-1}\right)$ by the predicted ${ }^{210} \mathrm{~Pb}$ flux for the same latitude based on soil ${ }^{210} \mathrm{~Pb}$ measurements from 41.5 to 81.5 degrees latitude as in ref (3). This method was previously used in a study of latitudinal gradients of PCBs (7) and is discussed in detail in an unpublished study (8).

Fluxes of $\mathrm{Al}$ were also calculated to investigate inputs of a primarily lithogenic element and $\mathrm{Al}$ FRs were calculated to estimate erosional and aeolian inputs to the lakes. After confirming a strong correlation between $\mathrm{Al} F R$ and the ratio of ${ }^{210} \mathrm{~Pb}$ derived recent and pre-industrial sedimentation rates $\left(\mathrm{r}^{2}=0.93, \mathrm{P}<0.001, \mathrm{~N}=12\right), \mathrm{Hg}$ fluxes for each horizon were adjusted for 
sedimentation and an adjusted anthropogenic $\mathrm{Hg}$ flux $\Delta \mathrm{F}_{\text {adj }}$ was calculated using the equation of Perry et al (9) :

$\Delta \mathrm{F}_{\mathrm{F}, \text { adj }}=\mathrm{F}_{\text {Frecent }}-\mathrm{F}_{\text {Fpre-ind }}\left(\mathrm{F}_{\text {Fpre-ind }} \mathrm{X}\right.$ sedimentation ratio- $\left.\mathrm{F}_{\text {Fpre-ind }}\right)$

\section{Additional Results and Discussion}

Sedimentation rates: Average sedimentation rates were 50-704 $\mathrm{g} \mathrm{m}^{-2} \mathrm{yr}^{-1}$ (Table S1) and cores from all lakes exhibited near-exponential declines in excess ${ }^{210} \mathrm{~Pb}$ with depth, indicating relatively constant rates of sediment accumulation (Figure S1). Latitude explained a portion $\left(r^{2}=0.31\right.$, $\mathrm{p}=0.04$ ) of the variation in sedimentation rates, as subarctic lakes located south of tree line tended to have higher sedimentation rates than higher latitude lakes (Figure S2). Half of the lakes examined here showed increases in sedimentation rates in recent years (post-1990) compared to pre-industrial times (Figure S3). Sedimentation rate increases in Char and West lakes were the most dramatic (122-192\% increases), while those in Amituk, SH-L4, Romulus, Fisherman, and Shipiskan were more moderate (6-44\% increases). Lake Hazen and DVE showed no change in sedimentation rate over time, Cli, BI-02, MB-AC, and Mista showed moderate decreases (8$44 \%)$, and BK-AH showed a strong decrease (71\%). The changes in sedimentation rates observed may be related to climate induced changes to precipitation, permafrost degradation, and catchment erosion (3). Our 14 study lakes span two Arctic Climate Impact Assessment (ACIA) regions, which are divided based on large-scale differences in climate and climate-shaping factors and are therefore expected to have different responses to climate change (10). Three of the four lakes (Cli, MB-AC, and BK-AH) which showed post-industrialization decreases in sedimentation rates fall within ACIA Region III, which encompasses the western Canadian Arctic, whereas all of our other sampled lakes fall within Region IV, which encompasses northeast Canada and Labrador. Furthermore, several of the lakes that experienced post- 1850 increases in sedimentation rate (Char, Amituk, West, and Romulus) are located in the central Canadian Arctic archipelago, which falls into ACIA Region IV and has experienced increases to mean annual snowfall in recent decades (10-11). 
Mercury: Sediment $\mathrm{Hg}$ concentrations varied from lake to lake (range 10-187 $\mathrm{ng} \mathrm{g}^{-1}$ dry weight $(\mathrm{dw}))$, and as with sedimentation rates, tended to decrease with latitude $\left(\mathrm{r}^{2}=0.32, \mathrm{p}=0.03\right)$.

Shipiskan Lake, for example, located in Labrador in the eastern Canadian subarctic, had the highest $\mathrm{Hg}$ sediment concentrations (mean \pm standard deviation; $149 \pm 14 \mathrm{ng} \mathrm{g}^{-1}$ ), whereas DVE Lake, located on Devon Island in the central Canadian high Arctic, had the lowest $\left(13 \pm 3 \mathrm{ng} \mathrm{g}^{-1}\right)$. With the exception of Lake Hazen, which showed little change over time, sediment $\mathrm{Hg}$ concentrations increased between 10 and $189 \%$ between modern and pre-industrial times (Figure S3) with EFs in the range of 1.1-2.6. Sediment $\mathrm{Hg}$ concentrations and EFs are comparable to those reported by others for the Canadian high and subarctic $(3,12-14)$. Since $\mathrm{Hg}$ concentrations reflect both sedimentation rates and $\mathrm{Hg}$ inputs to a lake, $\mathrm{Hg}$ fluxes were calculated to examine changes to $\mathrm{Hg}$ inputs to the lakes over time.

Average fluxes, corrected for sediment particle focusing $\left(\mathrm{F}_{\mathrm{F}}\right)$ (Table S1), were 1-72 $\mu \mathrm{g} \mathrm{m}^{-}$ ${ }^{2} \mathrm{y}^{-1}$. Unlike sedimentation rates and $\mathrm{Hg}$ concentrations, there was no relationship between average $\mathrm{Hg}$ fluxes and latitude $\left(\mathrm{r}^{2}=0.09, \mathrm{p}=0.29\right)$. Hg fluxes increased dramatically since industrialization in 11 of 14 of the lakes examined (Figure 2), with $\Delta \mathrm{HgF}_{\mathrm{F}}$ ranging from $2-24 \mu \mathrm{g}$ $\mathrm{m}^{-2} \mathrm{y}^{-1}$. Hg fluxes began increasing as early as the late 1800's/early 1900's in some lakes, but did not begin increasing until the 1930's-1960's in others (Figure S4). Although Hg fluxes appear to have leveled in recent years in some lakes, in nine of the 11 lakes that experienced increases in Hg fluxes since industrialization, Hg fluxes were 2-49\% higher between 1990-2000 than 19701990, suggesting that $\mathrm{Hg}$ fluxes are continuing to increase in many systems. Post-industrialization flux increases were most pronounced in Char, West, DVE, Amituk, SHI-L4, Mista, Cli, and Shipiskan lakes (65-292\% increases, FRs: 0.6-3.9) while those in BI-02, Romulus, and Fisherman were slightly more moderate (39-50\% higher, FRs: 1.4-1.5). Lake Hazen showed little change over time (FR: 1.0), while $\mathrm{Hg}$ fluxes in MB-AC and BK-AH lakes decreased by 30 and $48 \%$, respectively, since industrialization (FRs: 0.5 and 0.7 , respectively). Several of the lakes which experienced dramatic post-industrialization $\mathrm{Hg}$ flux increases were also characterized by marked increases in sedimentation rate, while the opposite was true of the lakes where there were dramatic decreases in $\mathrm{Hg}$ flux. Therefore, to tease apart $\mathrm{Hg}$ inputs from catchment erosion and other sources (which would include, for example, anthropogenic atmospheric sources), $\mathrm{HgF}_{\mathrm{F}}$ values were adjusted for post-industrialization changes in sedimentation rate to obtain $\mathrm{HgF}_{F, a d j}$ following the methods of ref (3). 
Average $\mathrm{HgF}_{\mathrm{F} \text {,adj }}$ were $57-110 \%$ lower than average $\mathrm{F}_{\mathrm{F}}$ values for each lake suggesting that a large portion of $\mathrm{Hg}$ inputs to high and subarctic lakes originates from catchment contributions. There was a significant relationship between latitude and $\Delta \operatorname{HgF}_{\mathrm{F}, \text { adj }}\left(\mathrm{r}^{2}=0.45\right.$, $\mathrm{p}=0.01$ ). Assuming that $\Delta \mathrm{HgF}_{\mathrm{F} \text {,adj }}$ mostly represents atmospheric $\mathrm{Hg}$ inputs, these results suggest that anthropogenic $\mathrm{Hg}$ deposition decreases slightly toward the north. $\mathrm{HgF}_{\mathrm{F} \text {,adj }}$ increased in all lakes since industrialization $\left(\Delta \mathrm{HgF}_{\mathrm{F}, \text { adj }}\right.$ were 0.3-16 $\left.\mu \mathrm{g} \mathrm{m}^{-2} \mathrm{y}^{-1}\right)$ (Table 1; Figure S4). Even in MB-AC and $\mathrm{BK}-\mathrm{AH}$, where $\mathrm{HgF}_{\mathrm{F}}$ decreased post-industrialization $\left(\Delta \mathrm{HgF}_{\mathrm{F}}\right.$ were -1 and $-5 \mu \mathrm{g} \mathrm{m}^{-2}$ $\mathrm{y}^{-1}$, respectively), $\Delta \mathrm{HgF}_{\mathrm{F}, \text { adj }}$ values were 0.8 and $0.9 \mu \mathrm{g} \mathrm{m}^{-2} \mathrm{y}^{-1}$, respectively, suggesting that while climate-induced catchment erosion may be impacted to some extent by localized factors, increases in anthropogenic atmospheric $\mathrm{Hg}$ deposition are widespread across the Canadian Arctic. Finally, due to the high contribution of soil $\mathrm{Hg}$ to lake sediment $\mathrm{Hg}$ flux, enhancement of $\mathrm{Hg}$ deposition by anthropogenic sources was "masked" by the high background fluxes and FR adj values were therefore much greater than FR values (average 6.3 versus 1.9). However FR adj was not calculated in $\sim$ half the study lakes because, after correction for changes in sedimentation rate, the preindustrial $\mathrm{F}_{\mathrm{F} \text {,adj }}$ was so small that it artificially inflated FR.

The $\Delta \mathrm{Hg}$ flux and FR values reported here are comparable to those observed in other Arctic lakes sampled in the period 1998-2005 (3). More recently, $\Delta \mathrm{HgF}$ and FRs values of $5 \mu \mathrm{g}$ $\mathrm{m}^{-2} \mathrm{y}^{-1}$ and 2.0, respectively, were observed in Kusawa Lake, Yukon (12). Interestingly, Cooke et al. (14) showed that, while $\Delta \mathrm{HgF}$ and FRs values were $2 \mu \mathrm{g} \mathrm{m}^{-2} \mathrm{y}^{-1}$, and 2-5, respectively, for 2 Baffin Island (Nunavut) lakes when the ${ }^{210} \mathrm{~Pb}$ dating method was used, values were much higher (3-4 $\mu \mathrm{g} \mathrm{m}^{-2} \mathrm{y}^{-1}$ and 12-13, respectively) when a composite ${ }^{210} \mathrm{~Pb}$ and ${ }^{14} \mathrm{C}$ dating method was used. Fitzgerald et al. (15) reported FRs of $\sim 1.5-4.2$ for 5 Alaskan lakes. None of the above studies reported $\Delta \mathrm{HgF}_{\mathrm{F}}$; however Fitzgerald et al. (2005) corrected fluxes for erosional contributions using catchment soil $\mathrm{Mg}: \mathrm{Hg}$ ratios and sediment $\mathrm{Mg}$ concentrations. Similar to our findings, they showed that $\mathrm{FR}_{\mathrm{adj}}$ values were higher than FR (3.2 versus 2.6) due to the masking of anthropogenic $\mathrm{HgF}$ enhancement by the relatively large soil $\mathrm{Hg}$ contribution. 


\section{References}

1) Glew, J.R., Smol, J.P., Last, W.M. Sediment core collection and extrusion. In Tracking Environmental Change Using Lake Sediments. Volume 1: Basin Analysis, Coring, and Chronological Techniques. Last, W.M. and Smol, J.P. Eds.; Kluwer Academic Publishers: Dordrecht, 2001.

2) Oldfield, F.; Appleby, P. G., Empirical testing of ${ }^{210} \mathrm{~Pb}$ dating models for lake sediments. In Lake Sediments and Environmental History, Haworth, E. Y.; Lund, J. W. G., Eds.; University of Minnesota Press: Minneapolis, 1984.

3) Muir, D. C. G.; Wang, X.; Yang, F.; Nguyen, N.; Jackson, T.; Evans, M.; Douglas, M.; Köck, G.; Lamoureux, S.; Pienitz, R.; Smol, J.; Vincent, W.; Dastoor, A., Spatial trends and historical deposition of mercury in eastern and northern Canada inferred from lake sediment cores. Environ. Sci. Technol. 2009, 43, 4802-4809.

4) Preiss, N.; Mélièes, M.-A.; Pourchet, M., A compilation of data on lead-210 concentration in surface air and fluxes at the air-surface water and water-sediment interfaces. J. Geophys. Res. 1996, 1001, 28847-28862.

5) Wolfe, A. P.; Miller, G. H.; Olsen, C. A.; Forman, S. L.; Doran, P. T.; Holmgren, S. U. Geochronology of high latitude lake sediments. In Developments in Paleoenvironmental Research, Vol. 8, Pienitz, R.; Douglas, M. S. V.; Smol, J. P., Eds.; Springer: New York, 2004.

6) Hermanson, M. H. ${ }^{210} \mathrm{~Pb}$ and ${ }^{137} \mathrm{Cs}$ chronology of sediments from small, shallow arctic lakes. Geochimica et Cosmochimica Acta 1990, 54, 1443-1451.

7) Muir, D. C. G.; Omelchenko, A.; Grift, N. P.; Savoie, D. A.; Lockhart, W. L.; Wilkinson, P.; Brunskill, G. J., Spatial trends and historical deposition of polychlorinated biphenyls in Canadian mid-latitude and arctic lake sediments. Environ. Sci. Technol. 1996, 30, 3609-3617.

8) Omelchenko, A.; Lockhart, W. L.; Wilkinson, P. Study of the Depositional Characteristics of the Lake Sediments across Canada with Pb-210 and Cs-137; Freshwater Institute, Department of Fisheries and Oceans: Winnipeg, MB, 1995.

9) Perry, E.; Norton, S. A.; Kamman, N. C.; Lorey, P. M.; Driscoll, C. T., Deconstruction of historic mercury accumulation in lake sediments, northeastern United States. Ecotoxicology 2005, 14, 85-99.

10) ACIA. Arctic Climate Impact Assessment; Cambridge University Press: New York, 2005. 
11) Michelutti, N.; Douglas, M. S. V.; Smol, J. P. Diatom response to recent climatic change in a high arctic lake (Char Lake, Cornwallis Island, Nunavut). Global Planet. Change 2003, 38, 257-271.

12) Stern, G. A.; Sanei, H.; Roach, P.; De La Ronde, J.; Outridge, P. M. Historical interrelated variations of mercury and aquatic organic matter in lake sediment cores from a subarctic lake in Yukon, Canada: Further evidence toward the algal-mercury scavenging hypothesis. Environ. Sci. Technol. 2009, 43, 7684-7690.

13) Carrie, J.; Wang, F.; Sanei, H.; Macdonald, R. W.; Outridge, P. M.; Stern, G. A. Increasing contaminant burdens in an arctic fish, burbot (Lota lota), in a warming climate. Environ. Sci. Technol. 2010, 44, 316-322.

14) Cooke, C. A.; Hobbs, W. O.; Neal, M.; Wolfe, A. P., Reliance on ${ }^{210} \mathrm{~Pb}$ chronology can compromise the inference of preindustrial hg flux to lake sediments. Environ. Sci. Technol. 2010, 44, 1998-2003.

15) Fitzgerald, W. F.; Engstrom, D. R.; Lamborg, C. H.; Tseng, C.-M.; Balcom, P. H.; Hammerschmidt, C. R. Modern and historic atmospheric mercury fluxes in northern Alaska: Global sources and Arctic depletion. Environ. Sci. Technol. 2005, 39, 557-568. 
Table S1. Lake and sediment characteristics of 14 Canadian high and subarctic lakes cored between 2000-2005.

\begin{tabular}{|c|c|c|c|c|c|c|c|c|c|}
\hline Lake & Location & $\underset{{ }^{\circ} \mathbf{N}}{\text { Latitude }}$ & $\begin{array}{c}\text { Longitude } \\
{ }^{\circ} \mathrm{W}\end{array}$ & $\begin{array}{c}\text { Collection } \\
\text { group }^{1}\end{array}$ & $\begin{array}{c}\text { Slice } \\
\text { thickness } \\
(\mathbf{c m})\end{array}$ & $\begin{array}{c}\mathbf{L A}{ }^{2} \\
\left(\mathbf{k m}^{2}\right)\end{array}$ & $\mathbf{A}_{\mathbf{C}} / \mathbf{A}_{\mathbf{L}}{ }^{3}$ & $\mathbf{F F}^{4}$ & $\begin{array}{c}\text { Average } \\
\text { Sedimentation } \\
\text { rate }^{5} \\
\left(\mathrm{~g} \mathrm{~m}^{-2} \mathbf{y}^{-1}\right.\end{array}$ \\
\hline Shipiskan & NFLB & 54.5 & 62.2 & NWRI & 1 & 50 & 138 & 3.1 & 176 \\
\hline Mista & MB & 55.5 & 93 & NWRI & 1 & 10 & 3.8 & 0.2 & 68 \\
\hline Fisherman & NWT & 60.2 & 123.6 & EC/Halliwell & 0.5 & 11 & 30.3 & 0.2 & 250 \\
\hline Cli & NWT & 62 & 122 & Evans & 1 & 3 & 1.8 & 2.2 & 191 \\
\hline SH-L4 & NU & 65 & 83.8 & NWRI & 0.5 & 0.085 & 189 & 1.8 & 219 \\
\hline BI-02 & NU & 73 & 80 & Pienitz & 0.5 & 0.033 & 9.2 & 0.9 & 190 \\
\hline BK-AH & NU & 73.4 & 119.4 & Douglas/Smol & 0.5 & 0.01 & 1.4 & 1.3 & 50 \\
\hline Char & NU & 74.6 & 94.8 & NWRI & 0.5 & 0.53 & 8.2 & 3.1 & 149 \\
\hline West & NU & 74.9 & 109.7 & Lamoureux & 0.5 & 1.4 & 5.7 & 1.7 & 245 \\
\hline Amituk & NU & 75 & 93.8 & Kock & 0.5 & 0.38 & 69.1 & 3.7 & 185 \\
\hline DVE & NU & 75.3 & 89.5 & Douglas/Lim & 0.5 & 0.01 & 24 & 0.5 & 128 \\
\hline MB-AC & NU & 76.2 & 119.2 & Douglas/Smol & 0.5 & 0.001 & 14.3 & 0.7 & 473 \\
\hline Romulus & NU & 79.5 & 85.1 & Vincent & 1 & 4.4 & 4.6 & 5.1 & 704 \\
\hline Hazen & $\mathrm{NU}$ & 82 & 70 & NWRI & 0.5 & 538 & 9.1 & 1.2 & 498 \\
\hline
\end{tabular}

${ }^{1}$ Collection group that conducted the field work. NWRI (Environment Canada Research Support Division, W. Vincent (University Laval), M. Douglas/D. Lim (University of Toronto), G. Kock (Queen's University), S. Lamoureux (Queen's University), D. Halliwell (Environment Canada Prairie and Northern Region).

${ }^{2} \mathrm{LA}=$ lake area

${ }^{3} \mathrm{~A}_{\mathrm{C}} / \mathrm{A}_{\mathrm{L}}=$ Catchment area/Lake area

${ }^{4} \mathrm{FF}=$ focusing factor.

${ }^{5}$ Sedimentation rate estimated using the CRS model based on excess ${ }^{210} \mathrm{~Pb}$ except with the exception of Lake Hazen. For Lake Hazen, the sedimentation rate reported in ref (7) was used. 

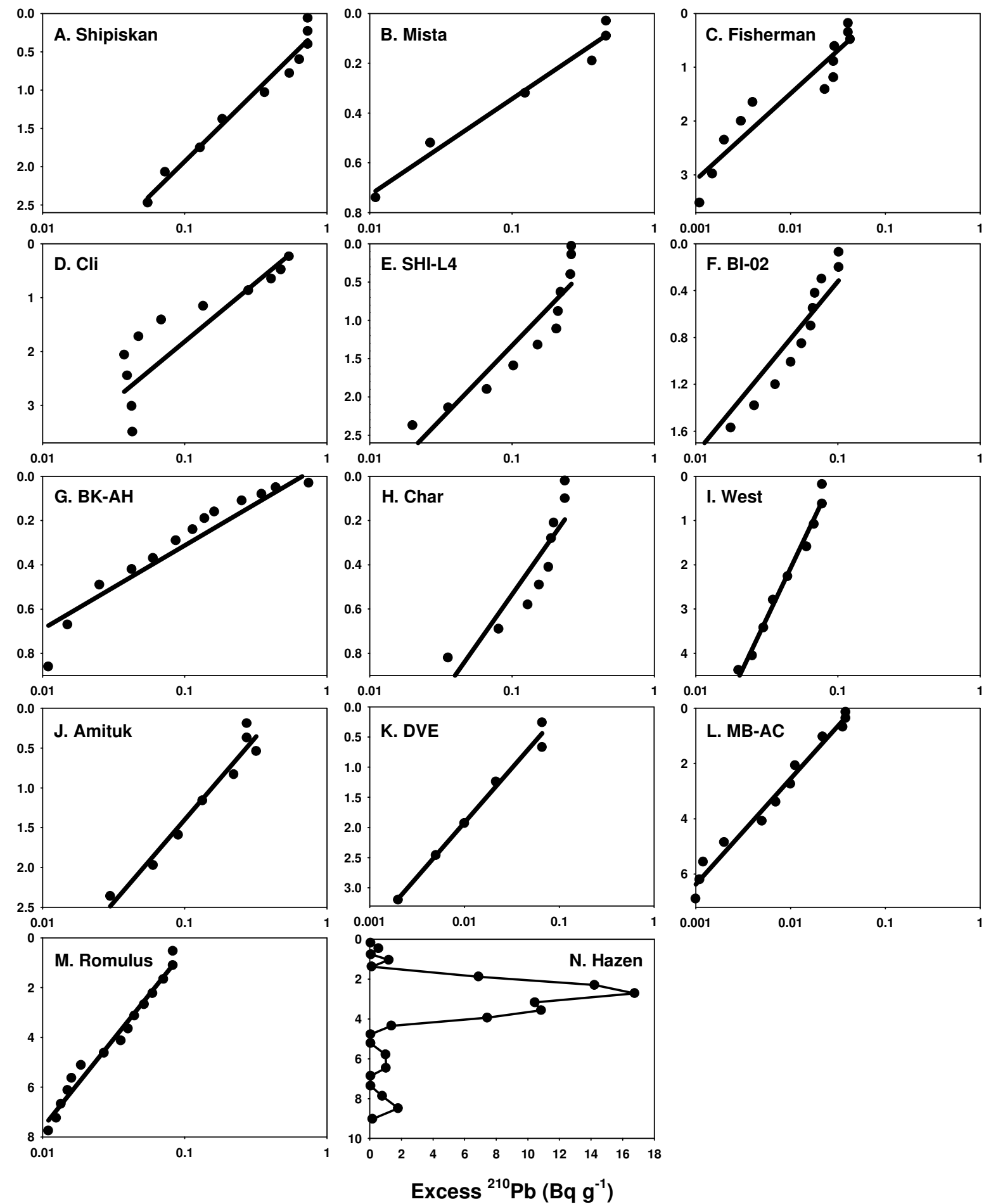

Fig

ure $\mathrm{S} 1$. Excess ${ }^{210} \mathrm{~Pb}$ plotted on a log scale versus accumulated dry weight measured in sediment cores from 13 Canadian high and subarctic lakes and ${ }^{137} \mathrm{Cs}$ versus depth for Lake Hazen. ${ }^{210} \mathrm{~Pb}$ and cumulative dry weight values represent measured, as well as, in some cases, interpolated and extrapolated values for each core section. Graphs are organized in order of latitude such that (A) is the most southerly lake sampled and $(\mathrm{N})$ the most northerly. 


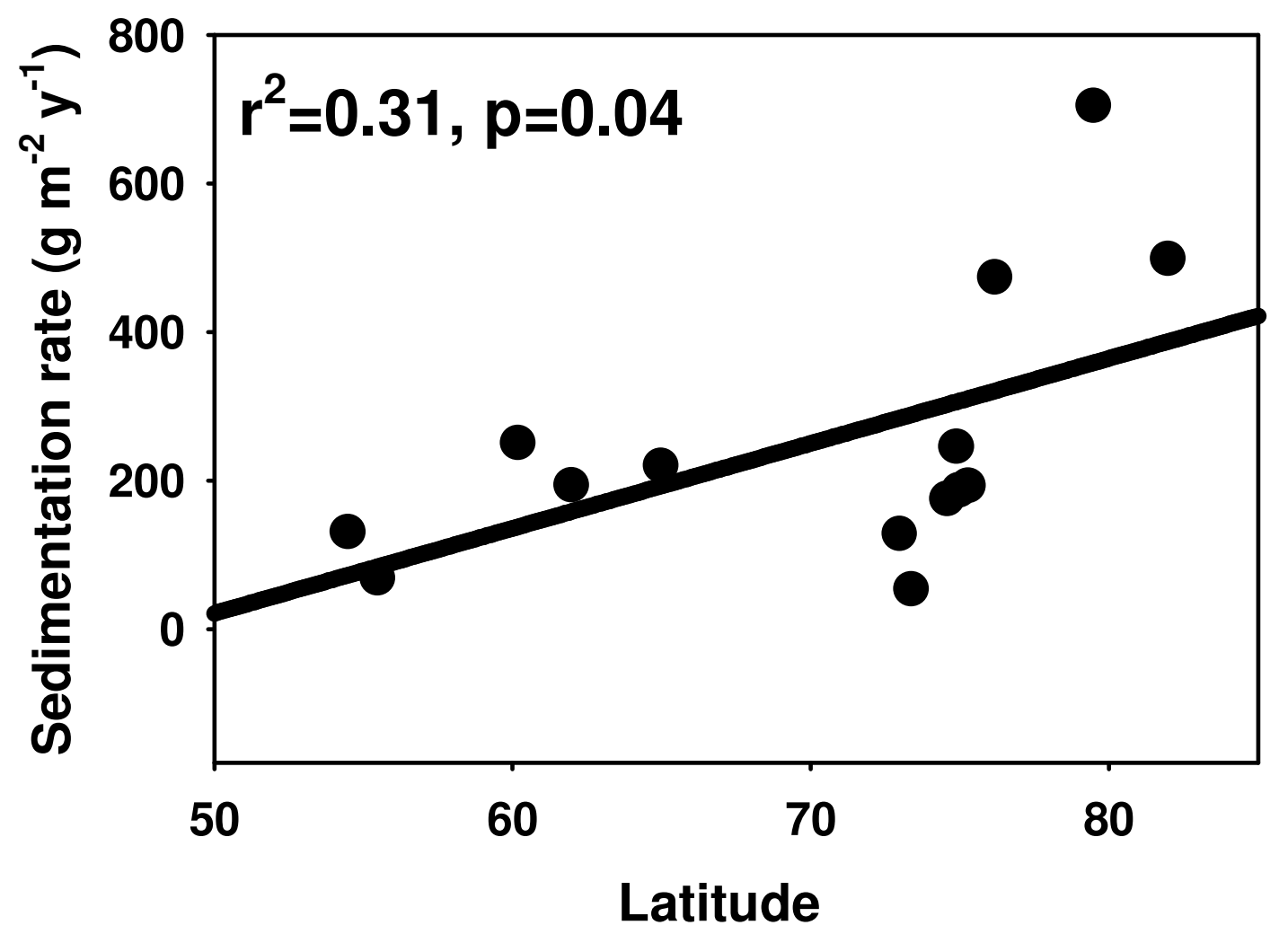

Figure S2. Relationship between average sedimentation rate $\left(\mathrm{g} \mathrm{m}^{-2} \mathrm{y}^{-1}\right)$ and latitude in 14 Canadian high and subarctic lakes. 
Sedimentation Rate $\left(\mathrm{g} \mathrm{m}^{-2} \mathrm{y}^{-1}\right)$
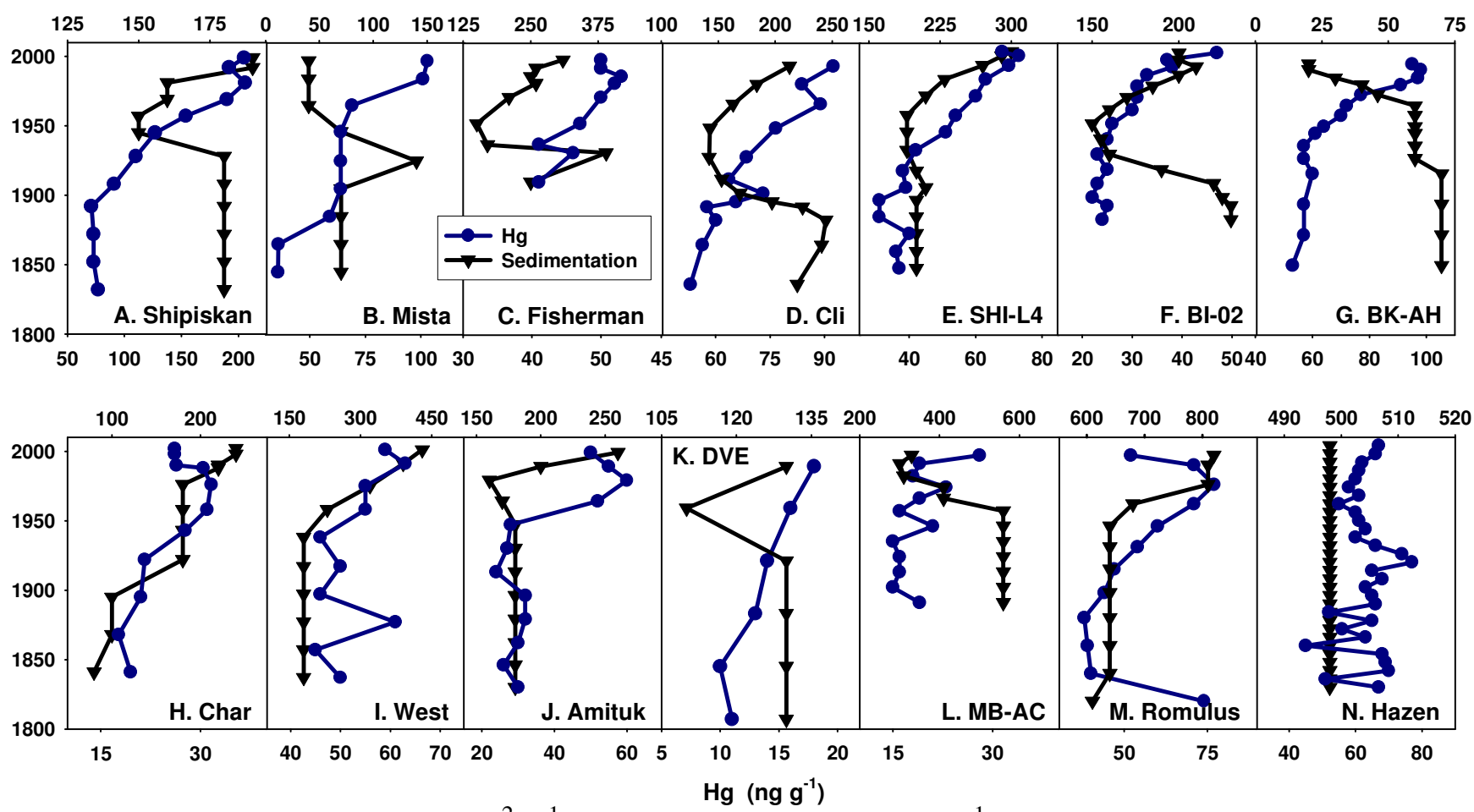

Figure S3. Sedimentation rate $\left(\mathrm{g} \mathrm{m}^{-2} \mathrm{y}^{-1}\right)$ and $\mathrm{Hg}$ concentration $\left(\mathrm{ng} \mathrm{g}^{-1}\right)$ through time measured in sediment cores from 14 Canadian high and subarctic lakes (A-N).
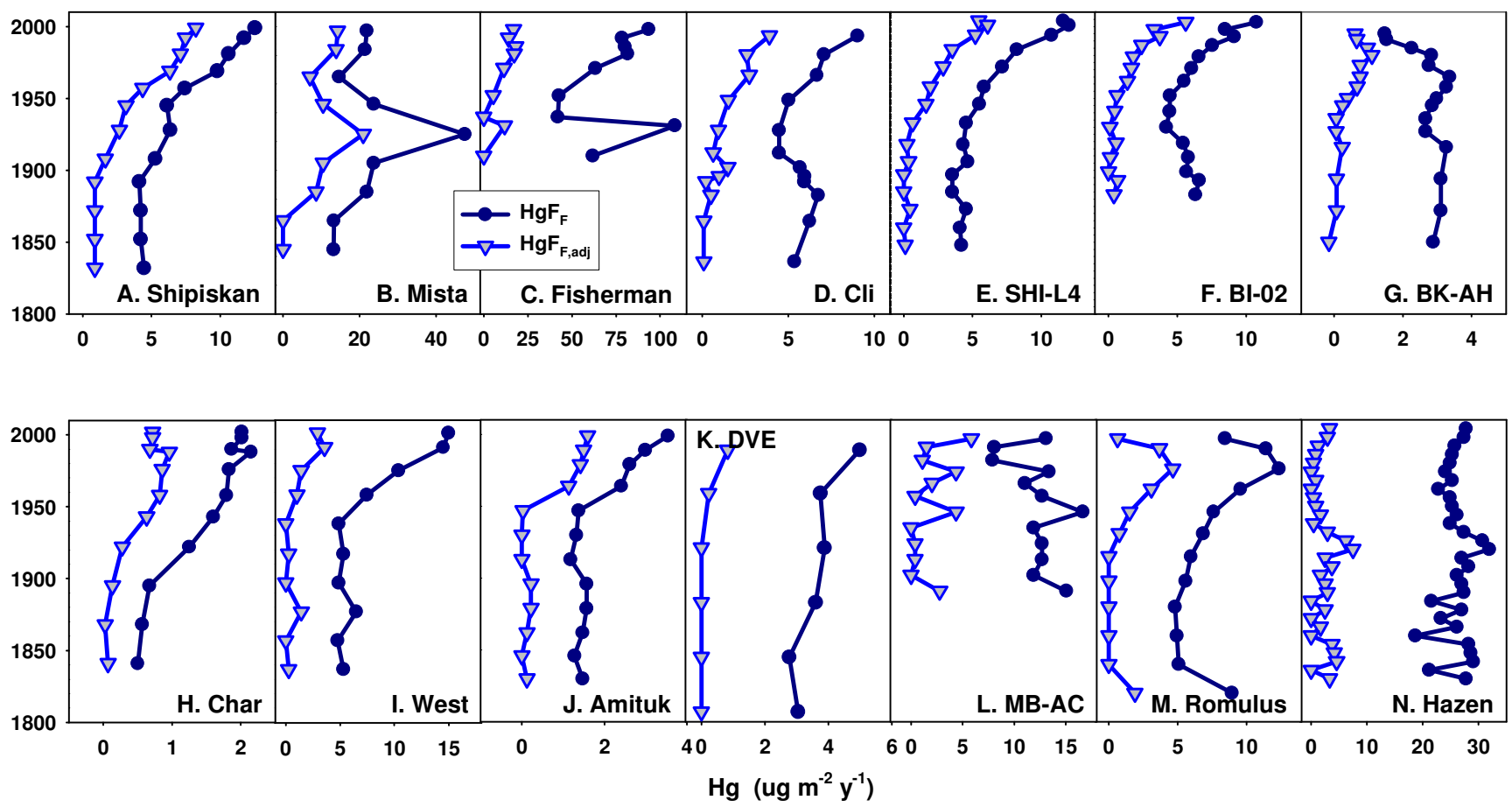

Figure S4. Hg fluxes adjusted for sediment particle focusing $\left(\mathrm{HgF}_{\mathrm{F}}\right)$ compared to $\mathrm{Hg}$ fluxes adjusted for sediment particle focusing and post-industrialization increases in sedimentation rate $\left(\mathrm{HgF}_{\mathrm{F}, \mathrm{adj}}\right)\left(\mu \mathrm{g} \mathrm{m}^{-2} \mathrm{y}^{-1}\right)$ in the 14 study lakes $(\mathrm{A}-\mathrm{N})$. 


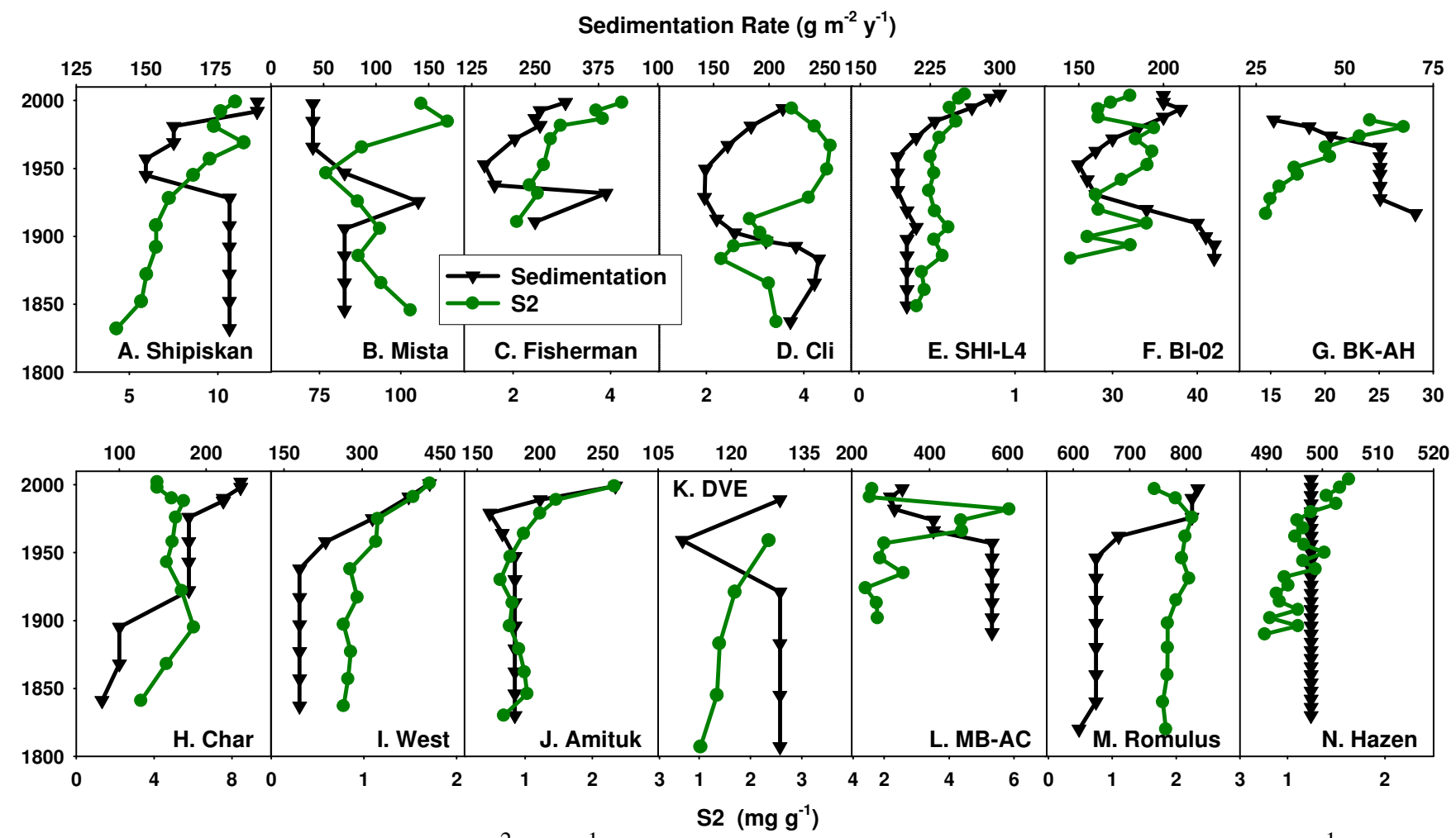

Figure S5. Sedimentation rate $\left(\mathrm{g} \mathrm{m}^{-2}\right.$ year $\left.{ }^{-1}\right)$ and algal derived carbon or $\mathrm{S} 2$ concentration $\left(\mathrm{ng} \mathrm{g}^{-1}\right)$ through time in the 14 study lakes $(\mathrm{A}-\mathrm{N})$.
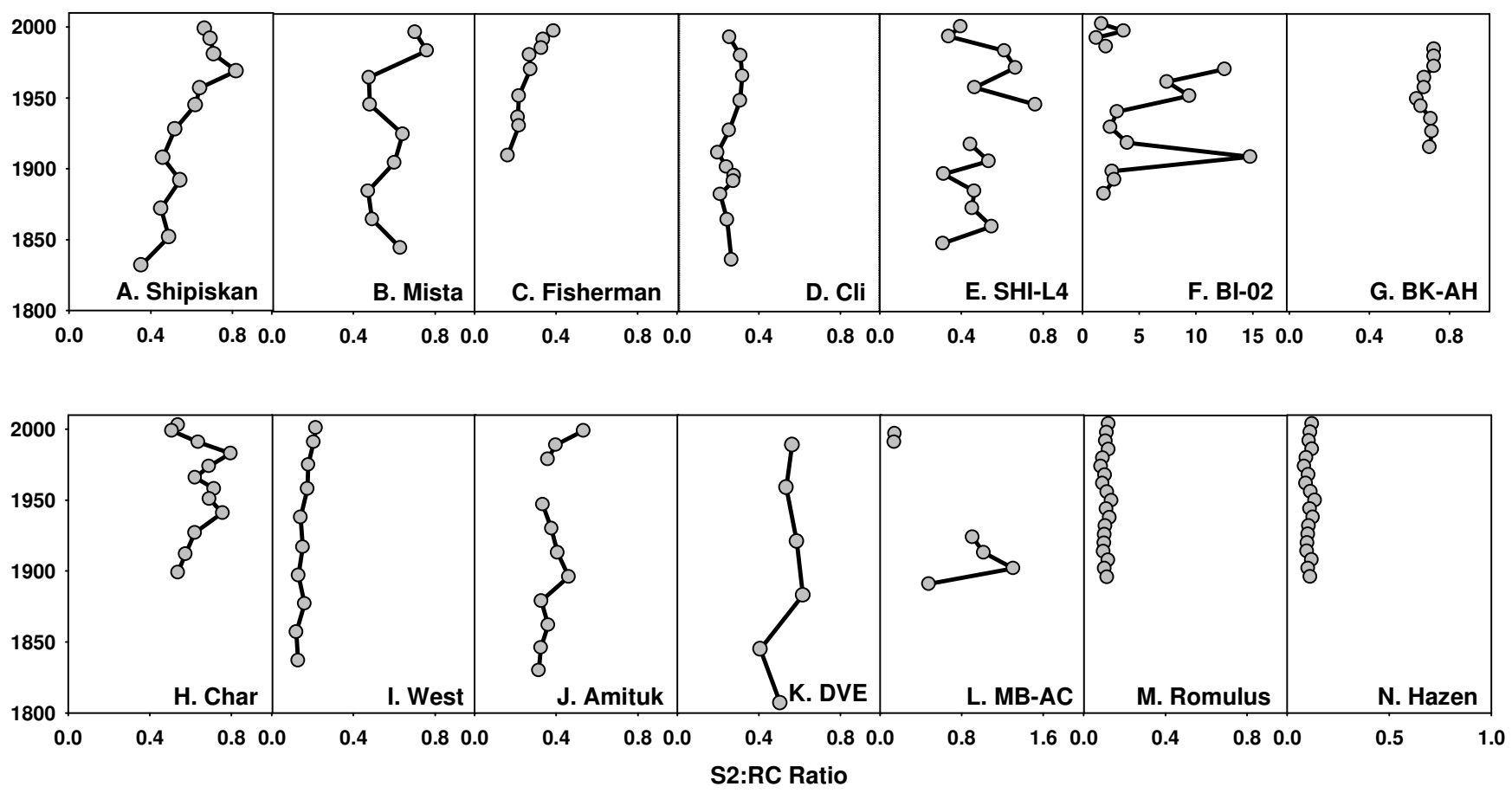

Figure S6. The ratio of algal derived carbon (S2) to residual carbon (RC) through time in the 14 study lakes (A-N). 


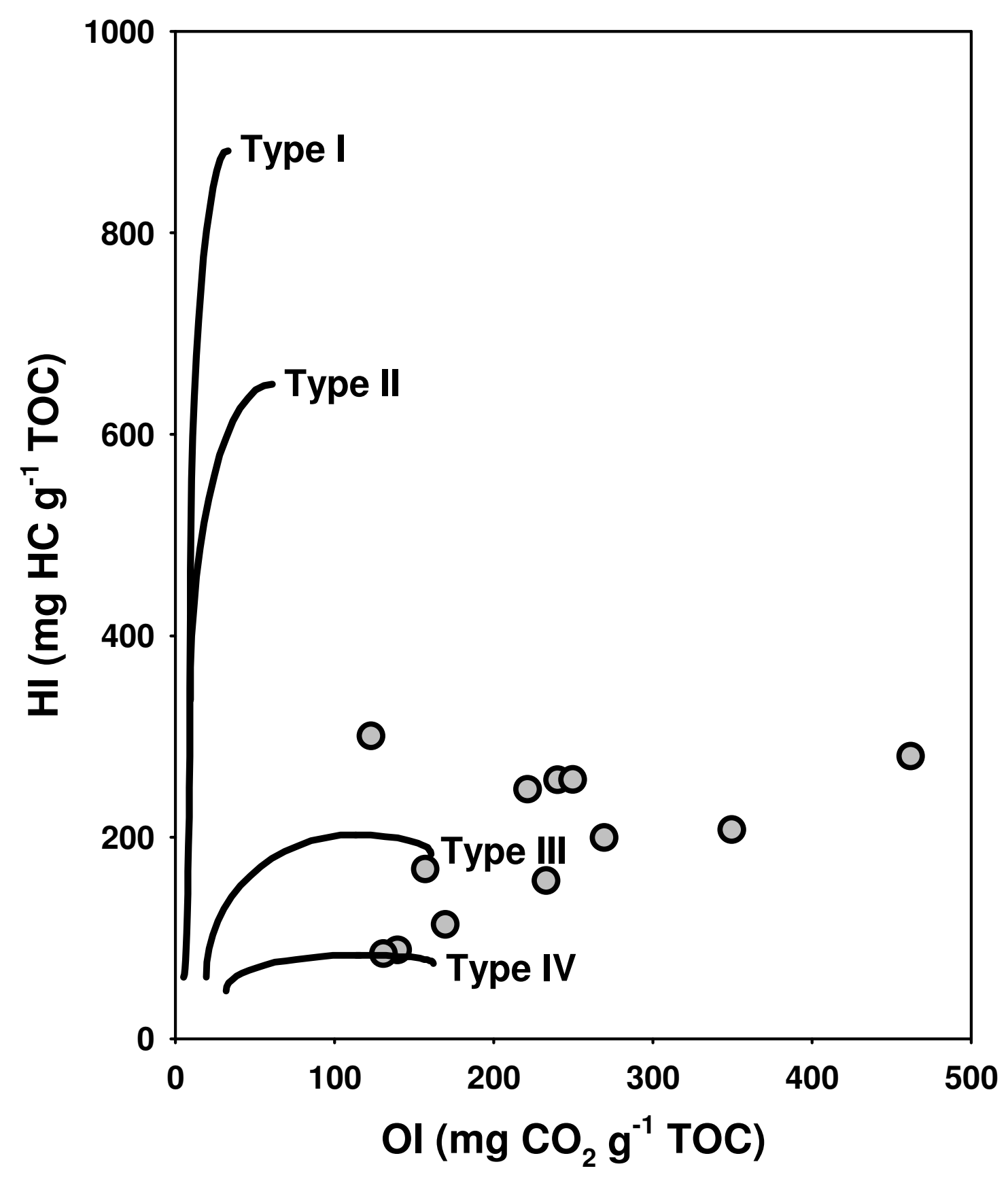

Figure S7. Van Krevelen diagram of sediments from 14 study lakes from across the Canadian high and Subarctic. Kerogen type is characterized in this diagram by plotting the relationship between average hydrogen index (HI; mg hydrocarbon (HC) $\mathrm{g}^{-1}$ total organic carbon (TOC)) and oxygen index (OI; $\mathrm{mg}$ carbon dioxide $\left.\left(\mathrm{CO}_{2}\right) \mathrm{g}^{-1} \mathrm{TOC}\right)$. 

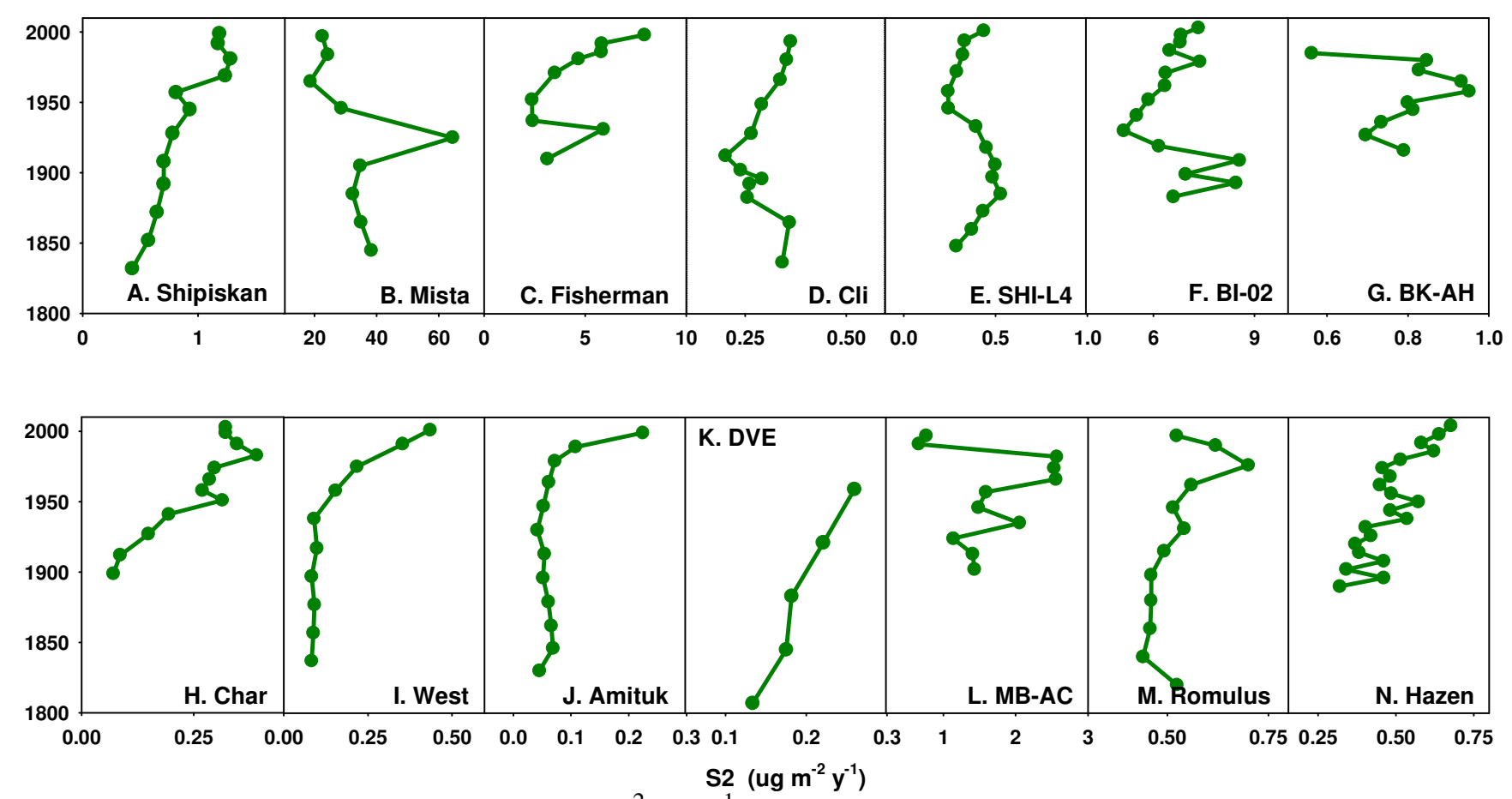

Figure S8. Algal derived C or S2 flux $\left(\mathrm{g} \mathrm{m}^{-2}\right.$ year $\left.^{-1}\right)$ through time in the 14 study lakes (A-N). 